\title{
Ways to improve the organization of dental care for workers in the chemical industry
}

\section{Jasur RIZAEV ${ }^{1}$, Rustam RAKHIMBERDIEV ${ }^{2}$, Nodira NAZAROVA ${ }^{3}$}

Samarkand State Medical Institute

\begin{tabular}{l} 
ARTICLE INFO \\
\hline Article history: \\
Received January 2021 \\
Received in revised form \\
15 January 2021 \\
Accepted 20 January 2021 \\
Available online \\
01 February 2021
\end{tabular}

\section{Keywords:}

mucous membrane

hard tissues of teeth

paradont

flavor analyzer

unfavorable production

factors.

\begin{abstract}
In recent years, studies have been carried out to study the problems of improving the organization of dental care both for the population as a whole and for certain categories of workers in industrial enterprises.

At the same time, to date, no in-depth studies have been carried out to study the problems of improving dental care for employees of a chemical industry enterprise, there is no comprehensive study of the current state of the dental service of the medical unit (MSU) of a large enterprise, there are no comparative data on the availability and quality of dental care for employees of the enterprise. place of residence and place of work.

The purpose of this review is to study the dental morbidity of chemical workers, to develop measures to improve the level of their dental health and improve the quality of life.

At the present stage of development of the industrial complex of our country, a number of large enterprises have the opportunity to organize dental care for workers with harmful working conditions, at a higher modern one. At the same time, the implementation of a preventive focus in dental care for the working population remains an unresolved problem to this day.

The successful functioning of any medical service in modern conditions largely depends on the level of organization and management of the activities of medical institutions, as well as the optimization of their work.
\end{abstract}

2181-1415/C 2021 in Science LLC.

This is an open access article under the Attribution 4.0 International (CC BY 4.0) license (https://creativecommons.org/licenses/by/4.0/deed.ru)

\footnotetext{
${ }^{1}$ Doctor of Medical Sciences, Professor, Rector of the Samarkand State Medical Institute, Samarkand, Uzbekistan E-mail: dr.Jasur@gmail.com

${ }^{2}$ Head of the Department of Pediatric Dentistry, Samarkand State Medical Institute, Samarkand, Uzbekistan

${ }^{3}$ Candidate of Medical Sciences, Associate Professor of the Department of Dentistry of the Faculty of Postgraduate Education, Samarkand state medical Institute, Samarkand, Uzbekistan E-mail: nazarova.uzb@gmail.com
} 


\section{Кимё саноати ишчилари учун стоматологик хизматни ташкил этишни такомиллаштириш йўллари}

\author{
Калит сўзлар: \\ Шиллиқ қават \\ Оғиз бўшлиғи \\ Тишларнинг қаттиқ \\ тўқималари \\ Парадонт \\ Таъм анализатори \\ Ноқулай ишлаб чиқариш \\ омиллари.
}

\section{АННОТАЦИЯ}

Сўнгги йилларда умумий ахоли учун хам, саноат корхоналари ходимларининг айрим тоифалари учун хам стоматологик ёрдамни ташкил этишни такомиллаштириш муаммоларини ўрганиш бўйича тадқиқотлар олиб борилмоқда.

Шу билан бирга, хозирги кунга қадар кимё саноати корхонаси ходимларига стоматологик ёрдамни такомиллаштириш муаммоларини ўрганиш бўйича чуқур тадқиқотлар олиб борилмаган, йирик корхонанинг тиббийсанитария бўлими (ТСБ) стоматологик хизматининг хозирги холатини хар томонлама ўрганмаган, корхона ходимларига яшаш жойида ва иш жойида стоматологик ёрдам кўрсатиш имконияти ва сифати тўғрисида қиёсий маълумотлар мавжуд эмас.

Ушбу шархнинг мақсади кимёвий ишлаб чиқариш ходимларининг тиш касалланишини ўрганиш, уларнинг тиш соғлиғини яхшилаш ва хаёт сифатини яхшилаш чоратадбирларини ишлаб чиқишдан иборат.

Мамлакатимиз саноат комплекси ривожланишининг хозирги босқичида бир қатор йирик корхоналар зарарли мехнат шароитлари бўлган ишчиларга стоматологик ёрдамни юқори замонавий шароитларда ташкил этиш имкониятига эга. Шу билан бирга, мехнатга лаёқатли ахолига стоматологик ёрдам кўрсатишда профилактика йўналишини амалга ошириш бугунги кунга қадар хал қилинмаган муаммо бўлиб қолмоқда.

Замонавий шароитда хар қандай тиббий хизматнинг муваффақиятли ишлаши кўп жихатдан тиббиёт муассасалари фаолиятини ташкил этиш ва бошқариш даражасига хамда уларнинг ишларини оптималлаштиришга боғлиқ.

\section{Пути}

совершенствования

стоматологического обслуживания

организации химической промышленности

\section{работников}

\section{АННОТАЦИЯ}

Ключевые слова:

слизистая оболочка

полость рта

твердые ткани зубов

парадонта

вкусовой анализатор

неблагоприятные

производственные

факторы.
В последние годы выполнены исследования, посвященные изучению проблем улучшения организации стоматологической помощи как населению в целом, так и отдельным категориям работников промышленных предприятий.

Вместе с тем, до настоящего времени не проводились углубленные исследования по изучению проблем совершенствования стоматологической помощи работникам предприятия химической промышленности, отсутствует 


\begin{abstract}
комплексное исследование современного состояния стоматологической службы медико-санитарной части (МСЧ) крупного предприятия, нет сравнительных данных доступности и качества стоматологической помощи работникам предприятия по месту жительства и по месту работы.

Целью данного обзора является изучить стоматологическую заболеваемость рабочих химического производства, разработать меры по улучшению уровня их стоматологического здоровья и повышения качества жизни.

На современном этапе развития промышленного комплекса нашей страны у целого ряда крупных предприятий появились возможности организовать стоматологическую помощь работникам с вредными условиями труда, на более высоком современном. Вместе с тем реализация профилактической направленности в стоматологическом обслуживании работающего населения остается до настоящего времени нерешенной проблемой.

Успешное функционирование любой медицинской службы в современных условиях во многом зависит от уровня организации и управления деятельностью лечебных учреждений, а тажке оптимизации их работы.
\end{abstract}

\title{
МАТЕРИАЛ И МЕТОДЫ ИССЛЕДОВАНИЯ.
}

Планируется провести исследование 120 рабочих АО «Самаркандкимё основная группа, а также 115 пациентов, обратившихся в поликлинику №10 и не имеющих отношение к химической промышленности, - контрольная группа.

Те данные, которые получили, подвергнуты статистической обработке с использованием пакета прикладных программ Microsoft Excel. Достоверность различия параметров определяли по критерию Стьюдента.

\section{РЕЗУЛЬТАТЫ И ОБСУЖДЕНИЕ}

В настоящее время вопросы стоматологического здоровья для рабочих различных отраслей промышленности являются актуальными.

Различные вредные факторы производства способны оказывать негативное влияние на состояние здоровья человека, в том числе и на ткани зубов, пародонта, слизистой оболочки рта и губ.

По данным литературы, отмечается более высокий уровень стоматологических заболеваний у работников вредных производств.

Одним из наиболее многочисленных контингентов, подвергающихся вредному воздействию факторов рабочей среды, являются работники, занятые занятых производством минеральных удобрений, гербицидов и пестицидов. Интенсивность воздействия факторов рабочей среды и трудового процесса обусловливает высокий риск нарушений здоровья работников данной отрасли экономики.

По данным многочисленных иследований на работников этих предприятий воздействует комплекс факторов рабочей среды и трудового процесса: производственный шум, вибрация, неблагоприятные параметры микроклимата, 
загрязнение воздуха рабочей зоны рудничной пылью и вредными веществами, отсутствие естественного освещения, а также значительные физические нагрузки.

Установлено, что вредные условия труда оказывают негативное влияние на состояние здоровья работающих, занятых производством минеральных удобрений, гербицидов и пестицидов и обусловливают у них опережающий рост заболеваний костно-мышечной и периферической нервной системы, сердечно-сосудистой системы, развитие инфарктов миокарда, мозговых инсультов, а также остеопений.

Анализ карт статистического учета и журнала регистрации, впервые выявленных профессиональных заболеваний ФБУН «Уфимский НИИ медицины труда и экологии человека», показал, что в РБ каждый год регистрируется от 150 до 200 вновь выявленных случаев профессиональных заболеваний. Ведущее место занимают нарушения опорно-двигательного аппарата (до 48,9\% случаев). На втором месте стоят заболевания, связанные с воздействием физических факторов нейросенсорная тугоухость, вибрационная болезнь (до 28\% случаев). На третьем месте (17\%) находятся заболевания, вызванные воздействием промышленных аэрозолей. Четвертое место составляют профессиональные аллергические заболевания.

При комплексном стоматологическом обследовании работников производства хлорорганических гербицидов, установлена высокая интенсивность кариеса зубов (индекс КПУ в основной группе составил $12,7 \pm 4,9$, в контроле $10,44 \pm 0,72)$, связанная авторами со стажем работы и степенью контакта работников с ксенобиотиками.

Средняя и тяжелая степень поражения пародонта у работников с трудовым стажем свыше 20 лет и у работников лаборатории была почти в два раза выше по сравнению с контрольной группой. Легкая степень поражения пародонта преобладала в первой и второй группах по стажу. С возрастанием стажа гигиеническое состояние полости рта ухудшается почти в 5 раз и оценивается в первой группе как неудовлетворительное, а во 2-ой и 3-ей как плохое. Также выявлена прямая взаимосвязь между степенью выраженности заболеваний слизистой оболочки полости рта, длительностью воздействия и степенью контакта рабочих с хлорфеноксигербицидами.

Отмечается тенденция к развитию гиперкератозов: хейлит, гиперкератоз красной каймы губ, слизистой щек и языка, плоская форма лейкоплакии красной каймы губ и слизистой щеки. В процессе исследования выявлено снижение гуморального компонента иммунитета, вследствие снижения уровня лизоцима и SIgA.

Данные исследований последних лет показали, что у работников предприятий резиновых и резинотехнических изделий, в зависимости от стажа работы, преобладают более тяжелые формы заболеваний тканей пародонта. При изучении стоматологической заболеваемости у работников стекольного производства кариес был выявлен у 98,3 \pm 1,0\% рабочих основных цехов, 59,5 \pm $7,6 \%$ - в контрольной группе. Хронический генерализованный пародонтит диагностировался в 100\% случаев, среди которых диагноз пародонтит легкой степени тяжести был поставлен у 31,4\% обследованных, средней степени - у 34,7\%, тяжелой степени - у 33,9\%. У 46,6\% работников была выявлена лейкоплакия слизистой оболочки полости рта, в контрольной группе - 28,0\%. 
У работников производства терефталевой кислоты выявлены патологии твердых тканей зубов кариозного и некариозного происхождения. Распространенность заболеваний пародонта составила 100\%, большей части обследованных требовалась квалифицированная стоматологическая помощь. Кроме того, выявлен высокий уровень заболеваний СОР, имеющий статистически значимую зависимость от стажа работы и профессии.

Анализ стоматологического статуса работников птицефабрики выявил высокую распространенность патологий твердых тканей зубов, тканей пародонта и слизистой оболочки рта. Из некариозных поражений полости рта диагностировались патологическая стираемость и клиновидный дефект. При изучении тканей пародонта установлено, что с увеличением стажа работы снижалось количество лиц с интактным пародонтом. Чаще всего среди заболеваний СОР встречались аллергические хейлиты, травматические поражения СОР, афтозные стоматиты, очаги гиперкератоза, прямо коррелирующие со стажем работников.

Согласно данным А.А. Агафонова (2012), у работников тепловой электростанции кариес встречается в 92,8\% случаев, его осложнения - в 47,9\%, пародонтиты - в 11,1\%, гингивиты - 20,4\%, пародонтоз - в 6,5\%, стоматиты - в 0,9\%, клиновидный дефект - в 6,7\% случаев. С увеличением стажа работы на вредном производстве повышается уровень заболеваний полости рта. Наиболее высокий показатель стоматологической заболеваемости обнаружен у рабочих котельнотурбинного цеха со стажем работы 5-10 лет.

Также, относительно показателей контрольной группы, отмечается низкий уровень секреторного иммуноглобулина А в ротовой жидкости работников

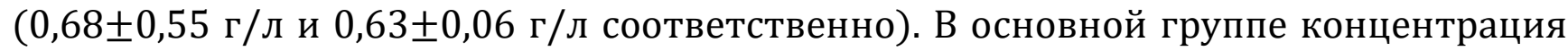
лизоцима слюны достоверно выше, чем в контрольной группе (соответственно $62,7 \pm 1,29 \%$ и $52,7 \pm 0,67 \%)$. В основной группе работников, в отличие от группы контроля, $\mathrm{pH}$ сдвигается в кислую сторону. В результате исследования были разработаны меры профилактики для улучшения условий труда и показателей здоровья работников.

Высокая распространенность стоматологических заболеваний диагностирована и у работников нефтехимического производства. Распространенность патологических процессов в тканях пародонта составила 100 \%, кариеса зубов - 99,1 \%, патологий слизистой оболочки полости рта - 58,7 \%. Выявлен низкий гигиенический уровень полости рта. При изучении концентрации иммуноглобулинов $\operatorname{sgA}, \operatorname{IgA}, \operatorname{IgM}, \operatorname{IgG}, \operatorname{IgE}$ и лизоцима в ротовой жидкости установлено, что у всех рабочих с заболеванием пародонта отмечается местный гуморальный иммунодефицит.

По данным стоматологического обследования рабочих производства минеральных удобрений происходит рост распространенности и интенсивности воспалительных заболеваний тканей пародонта с увеличением времени контакта с ксенобиотиками. Чаще всего были обнаружены признаки кровоточивости десен и зубного камня.

У работников был выявлен более высокий уровень заболеваний СОР -

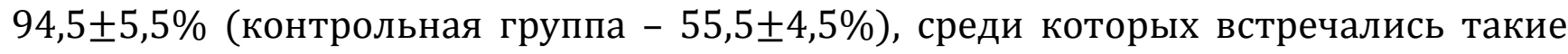
заболевания, как травматические поражения СОР, хронический рецидивирующий 
афтозный стоматит, хронический герпетический стоматит, метеорологический хейлит, десквамативный и гиперкератотический глоссит.. Также, в группе работников данного производства от 25 лет и старше, наблюдаются высокие значения интенсивности кариеса. Наряду с высокими показателями запломбированных зубов, некоторые исследователи связывают этот факт с высокой частотой удаления зубов по причине патологических процессов в тканях пародонта.

Воздействие факторов химико-радиационного производства на рабочих мужского пола, в возрасте от 55 до 64 лет и с большим трудовым стажем, изучены В.Н. Олесовой и др. Поражения твердых тканей зубов встречались в $100 \%$ случаев. Высокие значения индекса КПУ диагностировались у работников особо опасных производств $(18,4 \pm 3,3)$. Чаще всего выявлялось полное разрушение коронковой части зуба. Распространённость заболеваний слизистой оболочки полости рта достигала 27,4\%, что в 2 раза превышало соответствующий показатель у лиц контрольной группы.

У работников газоперерабатывающего завода рассматривалась зависимость распространенности и интенсивности кариозных поражений зубов от производственного стажа. Выяснилось, что общая распространённость кариозного процесса составила 90,5\%, интенсивность - 10,05 1 1,05. В зависимости от трудового стажа значения данных показателей увеличивались. У работников со стажем от 0 до 5 лет распространенность кариеса составила 86,5\%, интенсивность кариеса

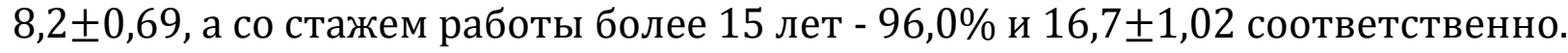

Анализ стоматологических заболеваний у работников предприятий алюминиевой промышленности по случаям нетрудоспособности за последние 5 лет показал, что основную долю по листкам нетрудоспособности составляют патологические процессы полости рта (58,65\%). Данный факт является подтверждением необходимости плановой санации полости рта у работников промышленности.

\section{Библиографические ссылки}

1. Абдазимов А.Д. Профилактика и лечение стоматологических заболеваний у рабочих, подвергшихся комбинированному воздействию полиметаллической пыли и токсических веществ: Дис. .... д-ра мед. наук.-Л., 1989.-347 с.

2. Антонов Н.С., Сахарова Г.М. Сравнительный анализ факторов риска развития бронхолегочных нарушений у подростков // Пульмонология. - Москва, 2011. - №4. - С. 44-48.

3. Аралов Н.Р. Распространенность болезней органов дыхания в табаководческом Ургутском районе республики Узбекистан // Вестн. ассоциации пульмонологов Центр. Азии. - 2000. - Вып.4 (№1-4). - С. 15-19.

4. Мамутов Р., Махкамов Н. Табак - здоровью враг // Народное слово. - Т., 2005. - №103 (31 мая). - С. 3.

5. Муминов Х. Кандай килиб, ВОЗ кечардим // Здравоохранение Узбекистана. - Т., 2005. - №21 (31 май). - С. 5.

6. Назарова Н.Ш., Жуматов У.Ж., Касимов М.М. Состояние вкусовой чувствительности у табаководов //Стоматология. - Т., 2011. - №3. -Л. - С. 18-20. 
7. 0 мерах по упорядочению деятельности по ферментации табачного сырья и производству табачных изделий: Постановление Кабинета Министров РУз от 7 сент. 2006г. №190. Прилож.№1. ПОЛОЖЕНИЕ о лицензировании деятельности по ферментации табачного сырья и производству табачных изделий // Собрание Постановлений Правительства Республики Узбекистан. - Т., 2006. - №9. - С. 60-72.

8. Обольский Д.М., Сокольская Т.А., Денисов А.А. Табак настоящий: химический состав, фармакологические свойства и применение в медицине // Фармация. - М., 2007. - №5. - С. 44-48.

9. Ballard T., Ehlers J., Freund E., Auslander M., Brandt V., Halperin W. Green tobacco sickness: occupational nicotine poisoning in tobacco workers //Arch Environ Health. 1995. - №50(5). - P. 384-9.

10. Bardin-Mikolajczak A., Lissowska J., Zaridze D., Szeszenia-Dabrowska N., Rudnai P., Fabianova E., Mates D. Occupation and risk of lung cancer in Central and Eastern Europe: the IARC multi-center case-control study //Cancer Causes Control. - 2007. - № 18(6). P.645-54.

11. Bozhkov I.A., Luchkevich V.S., Sevast'ianov M.A., Lopatin K.S. Impact of working conditions on morbidity accompanied by temporary disability in workers at the presentday tobacco plants //Gig Sanit. - 2005. - №1. - P.25-7.

12. Brown V.J. Tobacco's profit, workers' loss? // Environ Health Perspect. - 2003. - № 111(5).-P. 284-7. 